\title{
Model of risk management of construction project based on transaction costs
}

\author{
Irina Vladimirova ${ }^{1,}{ }^{*}$, Pavel Zemskov ${ }^{1}$, and Anna Tsygankova $^{1}$ \\ ${ }^{1}$ Plekhanov Russian University of Economic, Stremyanny per str., 36, Moscow, 117997, Russia
}

\begin{abstract}
The paper studies the relationship between transaction costs and risk management in the construction projects affecting ecosystem considering economic externalities. Quantitative indicators of the impact of transaction costs on the level of risk in the project are thoroughly investigated. The construction project risk management model based on transaction costs is discussed in detail. Collected and experimental data of the construction project, which has a significant impact on the ecology of the Baikal region in the Russian Federation is analyzed and the uncertainty reduction caused by transaction costs is measured.
\end{abstract}

\section{Introduction}

It is impossible to ensure environmental security of the territories and creating conditions for their sustainable development without the implementation of investment and construction projects. The construction project performance has an impact on the state of ecosystems and can lead to negative impacts for soil, air, water degradation and biodiversity loss. The degree of this impact depends on applied design solutions, building materials and equipment with special attention to the management of the construction project in accordance with environmental institutions. Therefore, in accordance with the institutional approach in construction project management, we must consider institutional factors of opportunism, incompleteness of information and bounded rationality. These factors can cause risks in construction projects and affect the value of the transaction costs and performance parameters. However, analysis of standards and research shows that models and methods of project management do not consider the influence of institutional factors on the level of project uncertainty that is associated with transaction costs $[1,3,6,2]$. The study was intended to develop a model for managing the risks in the construction project based on transaction costs for technical, economic and environmental subsystems.

\section{Literature review}

The International standard organization document states the processes of the environmental management system, but does not reflect costs of risk management [1]. Standards of leading project management associations describe project management processes without institutional factors $[3,6]$. However, total cost management processes in the integrated cost

\footnotetext{
* Corresponding author: kaf-stroy@yandex.ru
} 
management standard consider the impact of risks, but do not estimate costs and efficiency of preventive activities [2].

In previous studies of construction project risks and its impact on the ecosystem [Ошибка! Источник ссылки не найден.-Ошибка! Источник ссылки не найден.], the relationship between risks and transaction costs is ignored $[4,5,7]$. At the macro level, transaction costs are estimated at $45 \%$ of the gross domestic product, and at the construction sector transaction costs can be up to $200 \%$ of the construction cost [8]. However, there are no models using a correlation between the level of uncertainty in construction project and value of transaction costs. Earlier, the authors of this work showed methods of calculating transformation and transaction costs in investment construction projects, but probability factors were not considered [9-11]. It is important to emphasize that sustainable development of territories is modern concept of considering environmental aspects in economic processes. Ecological management has been transformed into green economy and must be analyzed in cost and investment efficiency estimation of the construction project [13-16].

\section{Materials and methods}

To develop a risk management model based on transaction costs we applied system analysis methods, institutional theory of transaction costs approach and microeconomic modeling. The study used data of the plant for transportation liquefied hydrocarbon gases construction in the Irkutsk region, that affects ecology of Baikal region in Russian Federation. Monte Carlo Simulation was used to obtain data for various scenarios considering uncertainty of performance construction project.

\section{Results}

The construction project risk management model based on transaction costs is shown in Fig. 1.

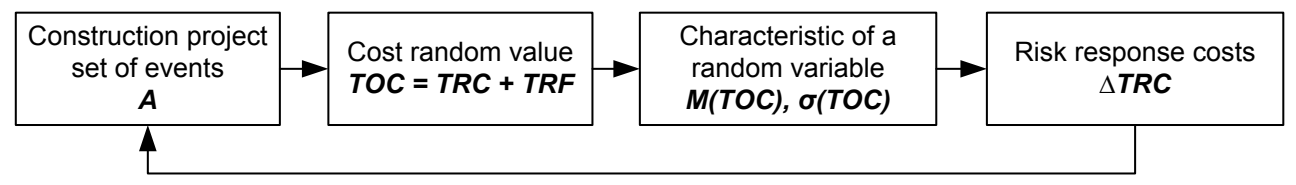

Fig. 1. Construction project risk management model based on transaction costs.

The model is based on the relationship between the level of uncertainty that causes risks in the construction project and the value of transaction costs. Institutional factors of incompleteness of information, opportunism and limited rationality [11] cause uncertainty in the construction project. That causes a set of possible events (A). The set of possible events lead to the stochastic factors that make the values of transformation (TRF) and transaction costs of construction project random. Consequently, total cost of the construction project (TOC) becomes random and it can be characterized by the values of the mathematical expectation $\mathrm{M}(\mathrm{TOC})$ and the standard deviation $\sigma$ (TOC). To specify these characteristics, project management team performs a risk response, which causes an increase in transaction costs $(\triangle \mathrm{TRC})$. This increase specifies the set of possible events in the construction project and changes the distribution of the random value of the construction project cost (TOC). As a result, the random value of the construction project cost gets specified characteristics, which indicates a reduction in the level of construction risks. These changes can be described by a point $\left(E_{M}, E_{\sigma}\right)$ of indicators with formulas 


$$
\begin{aligned}
\mathrm{E}_{\mathrm{M}} & =\frac{\Delta \mathrm{M}(\mathrm{TOC})}{\Delta \mathrm{TRC}}, \\
\mathrm{E}_{\sigma} & =\frac{\Delta \sigma(\mathrm{TOC})}{\Delta \mathrm{TRC}} .
\end{aligned}
$$

where TOC - cost of the construction project; $\triangle \mathrm{TRC}$ - transaction costs for risks response; $\Delta \mathrm{M}$-change in the mathematical expectation; $\Delta \sigma$ - change in the standard deviation. Associating the quantitative relations of uncertainty and increase in transaction costs, the model allows to evaluate efficiency of risk response activities in cost terms.

\section{Discussion}

Construction project performance affects ecological subsystem by the processes of design, production, delivery, consumption and utilization of products and services. Uncertainties arise on each stage of the construction project and therefore risks of environmental impact can be studied at construction, operation and decommissioning. However, further we will investigate risks of the construction stage.

Let us describe a set of possible events in the construction project. Denote by a $\in \mathrm{A}$ the event, which affects the objectives of the construction project. In the construction process, there are many determined, impossible and random events. Random events that may or may not occur under a certain set of conditions in construction are of primary interest for the construction management team. According to the neoinstitutional economy, factors of incompleteness of information, opportunistic behavior, and limited rationality must be considered in the construction project. These institutional factors create different sets of conditions $\mathrm{S}$, resulting in random events realization. A random event leads to variable consumption of construction project resources, which results in risks of project changes that negatively affect the team management goals. We classify the set A of random construction project events by risk areas of ecological, technical, organizational, financial and commercial subsets, Table 1.

Table 1. Classification of risk events in the construction project.

\begin{tabular}{|l|l|}
\hline $\begin{array}{c}\text { A subset of } \\
\text { construction } \\
\text { project events }\end{array}$ & \multicolumn{1}{c|}{ Risk events } \\
\hline Ecological area & $\begin{array}{l}\text { Events in the ecosystem that are realized during construction and lead to } \\
\text { environmental pollution, inefficient use of resources, generation of waste, } \\
\text { degradation of ecosystems and loss of biological diversity }\end{array}$ \\
\hline Technical area & $\begin{array}{l}\text { Events caused by factors in the technical subsystem by design, } \\
\text { construction, installation and commissioning works }\end{array}$ \\
\hline $\begin{array}{l}\text { Organizational } \\
\text { area }\end{array}$ & $\begin{array}{l}\text { Events in the social subsystem of the construction project, related to } \\
\text { coordination and communication in the process of planning, organization, } \\
\text { motivation and control }\end{array}$ \\
\hline Financial area & $\begin{array}{l}\text { Events related to financial flows of the construction project taking into } \\
\text { account payment conditions, exchange rates and inflation of currencies }\end{array}$ \\
\hline Commercial area & $\begin{array}{l}\text { Events associated with the factors of pricing on resource markets of the } \\
\text { construction project and selecting suppliers on a competitive and non- } \\
\text { competitive procurement schemes }\end{array}$ \\
\hline
\end{tabular}

In the construction project random events can affect the parameters of cost, schedule and quality [6]. For tracking their impact on the project objectives, the consequences of changes in schedule and quality are possible to translate into cost value. For example, a negative 
schedule deviation can be estimated in cost value form as the amount of lost profits of later facility commissioning. Decrease of quality of the plant under construction can be evaluated in terms of increased operating costs, production downtime due to poor engineering solutions, and payment of penalties for pollutant emissions. Further in work we assume that the consequences of random events in schedule and quality are translated into cost indicators.

The probability of realization event $a \in A$ is denoted as $p(a) \in P$. It is defined as the ratio of the number of interesting us construction project outcomes to the total number of project outcomes. The outcomes can be results of construction project performance, its stages or works with a given set of conditions $\mathrm{S}$.

Transformation costs are associated with the construction project technology and consumption production resources. It is calculated by the formula [10]:

$$
\mathrm{TRF}=\sum_{\mathrm{i}=1}^{\mathrm{a}} \mathrm{Lp}_{\mathrm{i}} * \mathrm{lp}_{\mathrm{i}}+\sum_{\mathrm{j}=1}^{\mathrm{b}} \mathrm{Mp}_{\mathrm{j}} * \mathrm{mp}_{\mathrm{j}}+\sum_{\mathrm{q}=1}^{\mathrm{c}} \mathrm{Kp}_{\mathrm{q}} * \mathrm{kp}_{\mathrm{q}}+\sum_{\mathrm{u}=1}^{\mathrm{d}} \mathrm{Cp}_{\mathrm{u}^{\prime}}
$$

where Lp - amount of labor in man-hours; $\mathrm{Mp}$ - the amount of resources in physical units of measurement; $\mathrm{Kp}$ - amount of machine hours; $\mathrm{Cp}_{\mathrm{u}}$ - cost of the $\mathrm{u}$-th contract for technological work; $\mathrm{lp}_{\mathrm{i}}, \mathrm{mp}_{\mathrm{j}}$, $\mathrm{kp}_{\mathrm{q}}$ - prices per unit of the resource; $\mathrm{a}, \mathrm{b}, \mathrm{c}$ - number of resource types in construction project; $\mathrm{d}$ - contracts for technological work.

Transaction costs are caused by adaptation of construction project changes in the internal and external environment (including ecosystem) to institutional improvement. It is calculated by the formula [10]:

$$
\mathrm{TRC}=\sum_{\mathrm{i}=1}^{\mathrm{d}} \mathrm{Lm}_{\mathrm{i}} * \mathrm{~lm}_{\mathrm{i}}+\sum_{\mathrm{j}=1}^{\mathrm{e}} \mathrm{Km}_{\mathrm{q}} * \mathrm{~km}_{\mathrm{q}}+\sum_{\mathrm{u}=1}^{\mathrm{h}} \mathrm{Cm}_{\mathrm{u}},
$$

where $\mathrm{Lm}$ - work amount of the project management team in man-hours; $\mathrm{Kp}$ - consumption hours amount of assets involved in project management; $\mathrm{Cm}_{\mathrm{u}}-$ cost of the $\mathrm{u}$ - th contract for managerial work; $\operatorname{lm}_{\mathrm{i}}, \mathrm{km}_{\mathrm{q}}$ - prices per unit of the resource; $\mathrm{d}$, e - number of construction project resource types; $\mathrm{h}$ - contracts for managerial work.

It may be noted that there is a relation between the transaction costs of construction project and negative impacts on the ecosystem. Transaction costs arise because of environmental legislative institutions which regulate externalities of ecosystem's pollution (e.g. in the form of a tax for polluting organizations). These institutions are aimed at the correction of market mechanism to achieve Pareto efficiency between construction participants and external stakeholders, including the local population and authorities. As a result, participants have to include transaction costs in the construction cost, prices of works and services that reduce their competitiveness.

The construction project cost is determined by the formula

$$
\mathrm{TOC}=\mathrm{TRF}+\mathrm{TRC} \text {. }
$$

Hence, continuously changing conditions of the external and internal environment create risks in the construction project. A positive increase in transaction costs

$$
\mathrm{TRC}_{1}-\mathrm{TRC}_{0}=\Delta \mathrm{TRC}>0,
$$

should reduce the overall level of risks for both construction project and ecosystem. It is necessary to quantify the relationship between the change in transaction costs and risks of the construction project.

Let us consider stochastic factors for Equation (5). We classify all events a $\in A$ into two disjoint subsets $A_{T R F} \cap A_{T R C}=\varnothing$. To the subset $A_{T R F}$ we refer events that affect the value 
of transformation costs, e.g. rise in cost of construction and installation works, changes in prices for equipment and materials. To the subset $A_{\text {TRC }}$ we refer events that affect transaction costs, e.g. increase in cost of management personnel salaries, costs for implementing environmental measures, including the use of organizational and technical solutions, materials, products, services or energy to reduce negative environmental impacts.

To be definite, assume that the cost parameter TOC takes one of the possible values TOC $=\left(\operatorname{toc}_{1}, \operatorname{toc}_{2}, \ldots\right.$ toc $\left.m\right)$ because of event a. Then TOC is a random variable with $\sum \mathrm{p}_{\mathrm{i}}=$ 1. Denote the probability of the cost random value $\mathrm{F}\left(\mathrm{TOC}_{\mathrm{i}}\right)$, then probability of the cost random value will be less $\mathrm{TOC}_{\mathrm{i}}$, i.e. $\mathrm{F}\left(\mathrm{TOC}_{\mathrm{i}}\right)=\mathrm{P}\left(\mathrm{TOC}_{\mathrm{i}}<\mathrm{TOC}\right)$. The probability that the construction costs will be greater than $\mathrm{TOC}_{1}$ and does not exceed TOC2 (Fig. 2) will be

$$
\mathrm{P}\left(\mathrm{TOC}_{1}<\mathrm{TOC}<\mathrm{TOC}_{2}\right)=\mathrm{F}\left(\mathrm{TOC}_{2}\right)-\mathrm{F}\left(\mathrm{TOC}_{1}\right) \text {. }
$$

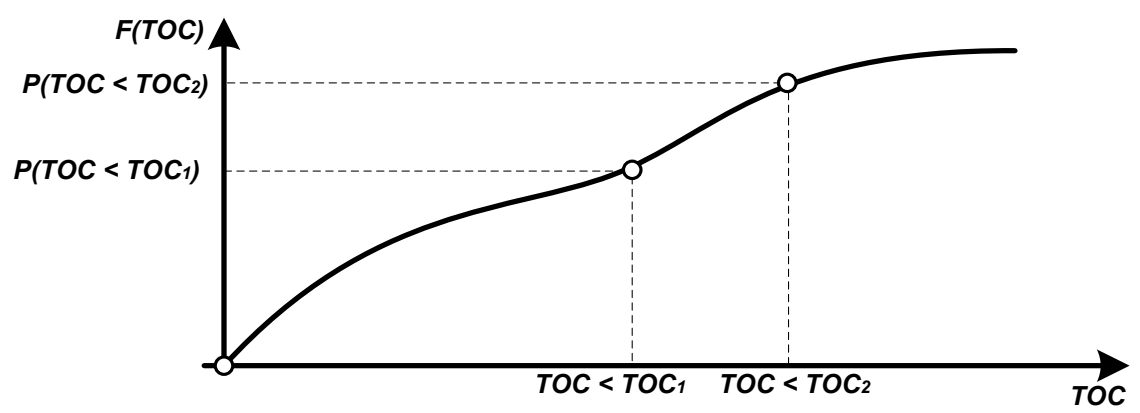

Fig. 2. Distribution function of construction project costs.

The density of the construction cost random value distribution is defined as

$$
f(T O C)=\lim _{\Delta \mathrm{TOC} \rightarrow 0} \frac{F(T O C+\Delta \mathrm{TOC})-\mathrm{F}(\mathrm{TOC})}{\Delta \mathrm{TOC}} .
$$

In case of a normal law the graph of the construction cost distribution density is shown in Fig. 3.



Fig. 3. Graph of the construction cost distribution density.

By using (4) the probability of being construction project cost in the interval $\left(\mathrm{TOC}_{1}\right.$, $\left.\mathrm{TOC}_{2}\right)$ is calculated as $\mathrm{P}\left(\mathrm{TOC}_{1}<\mathrm{TOC}<\mathrm{TOC}_{2}\right)=\int_{\mathrm{TOC}_{1}}^{\mathrm{TOC}_{2}} \mathrm{f}(\mathrm{TOC})$ dTOC. Mathematical expectation of construction cost value distributed over the interval $\left(\mathrm{TOC}_{1}, \mathrm{TOC}_{2}\right)$ is defined 
as $\mathrm{M}(\mathrm{TOC})=\int_{\mathrm{TOC}_{1}}^{\mathrm{TOC}_{2}} \mathrm{TOCf}(\mathrm{TOC}) \mathrm{dTOC}$. The standard deviation characterizes the spread of the cost value relative to the mathematical expectation on the interval $\left(\mathrm{TOC}_{1}, \mathrm{TOC}_{2}\right)$ calculates as $\sigma($ TOC $)=\sqrt{\int_{\mathrm{TOC}_{1}}^{\mathrm{TOC}_{2}} \text { TOC }-\mathrm{M}(\mathrm{TOC})^{2} \mathrm{f}(\mathrm{TOC}) \mathrm{dTOC}}$.

For construction project management there is a problem with collecting information about mass random events. It is caused by unique nature of construction project, interaction in space and time with a certain ecosystem, and an extended period of performance. At the same time, the costs of obtaining technical, economic and environmental data and knowledge may often exceed the benefits of decisions made on their basis. Therefore, in project management the Monte Carlo statistical test method is actively used, which allows simulating the repeated implementation of construction project in different scenarios and calculating the probability of various events.

Monte Carlo method is based on solving equations F(TOC) $=r_{i}$ or $\int_{-\infty}^{\text {TOC }_{i}} f($ TOC $) d T O C=$ $r_{i}$, where $r_{i}$ are the possible values of random variable $R$ distributed equally in the interval $(0,1)$. Form of the function $\mathrm{F}(\mathrm{TOC})$ is determined expertly or based on accumulated statistical data. Next, the values of the cost parameters are used into equation of the random construction cost value (5). As a result of this calculation, a large number of times (e.g. more than 10000$)$ distribution of the construction value is determined. In practice, calculations are performed by using application software.

Denote the random values of transformation and transaction costs as TRF and TRC with their distribution laws. For transformation costs the vectors of possible values and corresponding probabilities are represented as $\mathrm{TRF}=\left(\operatorname{trf}_{1}, \operatorname{trf}_{2}, \ldots \operatorname{trf} \mathrm{m}_{\mathrm{m}}\right)$ and $\mathrm{P}=$ $\left(\mathrm{p}_{1}, \mathrm{p}_{2}, \ldots \mathrm{p}_{\mathrm{m}}\right)$. By the same logic for transaction costs there are TRC $=\left(\operatorname{trc}_{1}, \operatorname{trc}_{2}, \ldots \operatorname{trc} \mathrm{tr}_{\mathrm{n}}\right)$ and $\mathrm{Q}=\left(\mathrm{q}_{1}, \mathrm{q}_{2}, \ldots \mathrm{q}_{\mathrm{n}}\right)$. Then the construction project cost is a function of two random variablesTOC $=\mathrm{TRF}+\mathrm{TRC}$. Its values can be described by the matrix $\mathbf{C}=\left(\mathrm{c}_{\mathrm{ij}}\right)$, where the element $c_{i j}$ is calculated from the formula $c_{i j}=\operatorname{trc}_{i}+\operatorname{trf}_{j}$ for the corresponding $i$-th value $\operatorname{trc}_{i}$ and $j$-th value of $\operatorname{trf}_{j}$

$$
\left(\begin{array}{ccc}
c_{11} & \cdots & c_{1 m} \\
\vdots & \ddots & \vdots \\
c_{n 1} & \cdots & c_{n m}
\end{array}\right) .
$$

The probability distribution of the random variable TOC is characterized by the matrix $\mathrm{R}$ $=\left(r_{i j}\right)$, where the element $r_{i j}$ is calculated from the formula $r_{i j}=q_{i} p_{j}$ for $i$-th probability value $\mathrm{TRC}_{\mathrm{i}}$ and the $\mathrm{j}$-th probability value $\mathrm{TRF}_{\mathrm{j}}$

$$
\left(\begin{array}{ccc}
r_{11} & \cdots & r_{1 m} \\
\vdots & \ddots & \vdots \\
r_{n 1} & \cdots & r_{n m}
\end{array}\right) .
$$

Then define the numerical characteristics of the random construction cost. The mathematical expectation and standard deviation are evaluated as

$$
\begin{gathered}
M(T O C)=M(T R F)+M(T R C), \\
\sigma(T O C)=\sqrt{\sigma^{2}(T R C)+\sigma^{2}(T R F) .}
\end{gathered}
$$

Assume that the construction project management team spends additional resources on risk management $\triangle \mathrm{TRC}$. Then according to (4) $\mathrm{TRC}_{1}-\mathrm{TRC}_{0}=\Delta \mathrm{TRC}>0$. The increase in costs is economically interpreted as the consumption of additional resources in construction project for risk management activities, including the implementation of environmental protection measures. These measures are aimed at minimizing the influence of negative events, e.g. through guarantees, insurance, creation of additional stocks, purchases at inflated 
prices from suppliers with reliable reputation, environmental licensing and certification. As a result of these activities, the probabilities of random variables TRC and TRF change on the $\mathrm{P}^{\prime}=\left(\mathrm{p}_{1}{ }^{\prime}, \mathrm{p}_{2}{ }^{\prime}, \ldots \mathrm{p}_{\mathrm{m}}{ }^{\prime}\right)$ and $\mathrm{Q}=\left(\mathrm{q}_{1}{ }^{\prime}, \mathrm{q}_{2}{ }^{\prime}, \ldots \mathrm{q}_{\mathrm{n}}{ }^{\prime}\right)$. Since transaction costs value is changed by the additional costs $\triangle \mathrm{TRC}$ and the probabilities in the distribution laws of TRF and TRC, this will affect their numerical characteristics. Then consider this change in more detail.

Denote by $f_{0}$ the distribution density of a random variable before taking measures to respond to risks, and by $f_{1}$ - the distribution density of a random variable after taking measures to respond to risks. Graphs of the distribution density are shown in Fig. 3. Due to the change in the distribution density, the mathematical expectation changes from $M_{0}$ to $M_{1}$ and the standard deviation from $\sigma_{0}$ to $\sigma_{1}$.

Since this change in the numerical characteristics of the construction cost random value was caused by $\triangle \mathrm{TRC}$, it is possible to quantify the contemporary change of two indicators for the mathematical expectation and standard variance:

$$
\begin{gathered}
E_{M}=\frac{M_{1}(\text { TOC })-M_{0}(\text { TOC })}{\mathrm{TRC}_{1}-\mathrm{TRC}_{0}}=\frac{\Delta M(\text { TOC })}{\Delta \mathrm{TRC}} . \\
\mathrm{E}_{\sigma}=\frac{\sigma_{1}(\mathrm{TOC})-\sigma_{0}(\mathrm{TOC})}{\mathrm{TRC}_{1}-\mathrm{TRC}_{0}}=\frac{\Delta \sigma(\mathrm{TOC})}{\Delta \mathrm{TRC}} .
\end{gathered}
$$

The indicators have the dimension [monetary units/monetary units]. The indicator (11) reflects how many monetary units of change in mathematical expectation are calculated for one monetary unit of the corresponding change in transaction costs. In other words, the indicator says how many monetary units the construction management team can specify the expected construction cost value, if they increase the transaction costs per unit. At the same time, the indicator (12) reflects how many monetary units of the change in the standard deviation are calculated for one monetary unit of transaction costs. In other words, how many monetary units it is possible to specify the spread of the construction cost value, if construction management team increases the transaction costs per unit. If $\mathrm{E}_{\mathrm{M}}<0$ or $\sigma_{\mathrm{M}}<$ 0 , the allocation of additional transaction costs in response to risks is effective, since it leads to the expected cost savings of the construction project.

The described approach was applied to construct a model for estimating the efficiency of risk response in the construction project of the liquefied petroleum gas (LPG) plant in the Russian Federation, which has a significant impact on the ecology of the Baikal region, Table 2 .

Table 2. Parameters of the LPG plant construction project in the Baikal region of the Russian Federation.

\begin{tabular}{|l|r|}
\hline \multicolumn{1}{|c|}{ Parameter } & \multicolumn{1}{|c|}{ Value } \\
\hline 1. Duration of construction project, year & 5 \\
\hline 2. Average number of transactions per activity, units & 58,77 \\
\hline 3. Cost of the construction project (TOC), million RUB & 3035 \\
\hline 4. Transaction costs (TRC), million RUB & 289 \\
\hline 5. Transformation costs (TRF), million RUB & 5761 \\
\hline 6.Net present value (E), million RUB & 25 \\
\hline 7. Duration of operation, year & \\
\hline
\end{tabular}

The initial distribution of the random value of the construction project cost is presented in a discrete form, for which $\mathrm{M}(\mathrm{TOC})=3035$ million RUB, $\sigma(\mathrm{TOC})=394,55$ million RUB, Table 3 .

Table 3. Initial cost sharing of the ISI.

\begin{tabular}{|l|l|l|l|l|l|l|l|l|l|}
\hline $\begin{array}{l}\text { TOC, million } \\
\text { RUB }\end{array}$ & 2246 & 2443 & 2640 & 2838 & 3035 & 3232 & 3430 & 3627 & 3824 \\
\hline
\end{tabular}




\begin{tabular}{|l|r|r|r|r|r|r|r|r|r|}
\hline $\mathbf{p}$ (TOC) & $\begin{array}{r}5,625 \\
\%\end{array}$ & $\begin{array}{r}8,867 \\
\%\end{array}$ & $\begin{aligned} 12,272 \\
\%\end{aligned}$ & $\begin{array}{r}14,914 \\
\%\end{array}$ & $\begin{array}{r}15,915 \\
\%\end{array}$ & $\begin{array}{r}14,914 \\
\%\end{array}$ & $\begin{array}{r}12,272 \\
\%\end{array}$ & $\begin{array}{r}8,867 \\
\%\end{array}$ & $\begin{array}{r}5,625 \\
\%\end{array}$ \\
\hline
\end{tabular}

Construction project performance includes a set of risk events in the environmental, technical, organizational, financial and commercial areas. A plan of measures for responding to these risks has been developed by the construction project team, Table 4 .

Table 4. The Plan of measures for responding to risks.

\begin{tabular}{|l|l|l|}
\hline Risk events & $\begin{array}{l}\text { Impact on type of } \\
\text { project costs }\end{array}$ & \multicolumn{1}{c|}{ Response activities } \\
\hline $\begin{array}{l}\text { Ecological } \\
\text { area }\end{array}$ & Transaction costs & $\begin{array}{l}\text { Environmental assessment and monitoring of } \\
\text { construction } \\
\text { Introducing the environmental management system } \\
\text { processes } \\
\text { Prevention or mitigation of adverse environmental } \\
\text { impacts }\end{array}$ \\
\hline Technical area & $\begin{array}{l}\text { Transformation } \\
\text { costs }\end{array}$ & $\begin{array}{l}\text { Contracting technical consultants } \\
\text { Reduction of inventories at the construction site }\end{array}$ \\
\hline $\begin{array}{l}\text { Organizational } \\
\text { area }\end{array}$ & Transaction costs & $\begin{array}{l}\text { Expansion of administrative staff } \\
\text { Introducing the risk management processes } \\
\text { Implementing the information system }\end{array}$ \\
\hline Financial area & Transaction costs & $\begin{array}{l}\text { Insurance } \\
\text { Hedging }\end{array}$ \\
\hline $\begin{array}{l}\text { Commercial } \\
\text { area }\end{array}$ & Transaction costs & $\begin{array}{l}\text { Contracting commercial consultants } \\
\text { Improving the procurement system } \\
\text { Introducing the guarantee system }\end{array}$ \\
\hline
\end{tabular}

These activities require additional costs for specifying design and construction solutions, insurance and price optimization through additional procurement procedures, specifying requirements and elimination of inefficient and high-risk solutions from the construction project scope. For each event was conducted an expert survey to identify the factors of their occurrence. For each factor were developed measures for responding to risks and were estimated the values of their upper and lower boundaries, and the most probable estimates based on three points method [6]. Then, for the factors, the variance was evaluated and the most appropriate probability distribution was chosen: uniform, normal, logarithmic, triangular, beta-distribution. As a result, a new distribution of transformation and transaction costs was obtained, Table 5.

Table 5. Distribution of cost components considering the risk response plan.

\begin{tabular}{|l|r|r|r|r|r|r|r|r|r|}
\hline \multicolumn{1}{|c|}{ Parameter } & \multicolumn{7}{|c|}{ Value } \\
\hline TRF, million & 1755,1 & 1801,7 & 1848,3 & 1894,9 & 1941,5 & 1988,1 & 2034,7 & 2081,3 & 2127,9 \\
RUB & 6 & 6 & 6 & 5 & 5 & 4 & 4 & 4 & 3 \\
\hline & 28,96 & 33,32 & 36,82 & 39,10 & 39,89 & 39,10 & 36,82 & 33,32 & 28,96 \\
p(TRF) & $\%$ & $\%$ & $\%$ & $\%$ & $\%$ & $\%$ & $\%$ & $\%$ & $\%$ \\
\hline TRC, million & & & & 1020,3 & 1045,4 & 1070,5 & 1095,6 & 1120,7 & 1145,8 \\
RUB & 945,08 & 970,17 & 995,27 & 5 & 5 & 4 & 3 & 2 & 1 \\
\hline & 19,41 & 26,60 & 33,32 & 38,13 & 39,89 & 38,13 & 33,32 & 26,60 & 19,41 \\
p(TRC) & $\%$ & $\%$ & $\%$ & $\%$ & $\%$ & $\%$ & $\%$ & $\%$ & $\%$ \\
\hline
\end{tabular}

For them: $\mathrm{M}(\mathrm{TRF})=1941.55$ million RUB, $\sigma(\mathrm{TRF})=232.99$ million $\mathrm{RUB}, \mathrm{M}(\mathrm{TRC})=$ 1045.45 million RUB, $\sigma(\mathrm{TRF})=83.64$ million RUB. The expected increase in the transformation costs is 1045.45 million RUB. For transaction costs the expected increase is 156 million RUB. This increase is caused by the costs of additional resources to minimize risks by hiring additional staff in the construction project management team, contracting 
consultants, implementing an environmental management system with risk management standards, and developing an information system. Since $\frac{\Delta \mathrm{TRF}}{\Delta \mathrm{TRC}}=\frac{-203}{156}=1.3$, then for 1 RUB of increase transaction costs there is a saving of $1.3 \mathrm{RUB}$ of transformation costs.

Considering formulas (9) and (10), a new project construction cost distribution was obtained, Table 6 .

Table 6. Distribution of the construction project cost considering the risk response plan.

\begin{tabular}{|l|r|r|r|r|r|r|r|r|r|}
\hline TOC, million & & & & $\mathbf{2 8 9 7}$ & $\mathbf{2 9 8 7}$ & & & & \\
RUB & $\mathbf{2 6 2 9}$ & $\mathbf{2 7 1 8}$ & $\mathbf{2 8 0 8}$ & $\mathbf{3 9}$ & $\mathbf{0 0}$ & $\mathbf{3 0 7 7}$ & $\mathbf{3 1 6 6}$ & $\mathbf{3 2 5 6}$ & $\mathbf{3 3 4 5}$ \\
\hline & 5.625 & 8.867 & 12.27 & 14.91 & 15.91 & 14.91 & 12.27 & 8.867 & 5.625 \\
p(TOC) & $\%$ & $\%$ & $2 \%$ & $4 \%$ & $5 \%$ & $4 \%$ & $2 \%$ & $\%$ & $\%$ \\
\hline
\end{tabular}

Make comparison of construction project cost indicators before and after the response to risks, Table 7.

Table 7. Comparison of construction project cost parameters.

\begin{tabular}{|c|c|c|c|}
\hline $\begin{array}{c}\text { Indicator, } \\
\text { million RUB }\end{array}$ & Before the risk response & After the risk response & Change \\
\hline $\mathrm{M}(\mathrm{TOC})$ & 3035 & 2987 & -48 \\
\hline $\mathrm{M}(\mathrm{TRC})$ & 889 & 1045 & 156 \\
\hline $\mathrm{M}(\mathrm{TRF})$ & 2145 & 1942 & -203 \\
\hline
\end{tabular}

Considering formulas (9) and (10) for a new construction project cost distribution, the mathematical expectation and standard deviation are

$$
\begin{gathered}
M(\text { TOC })=M(\text { TRF })+M(T R C)=2987 \text { million RUB., } \\
\sigma(\text { TOC })=\sqrt{\sigma^{2}(\mathrm{TRC})+\sigma^{2}(\mathrm{TRF})}=247,54 \text { million RUB. }
\end{gathered}
$$

Let us calculate the change in the mathematical expectation and variance using formulas (11) and (12). $\Delta \mathrm{M}(\mathrm{TOC})=\mathrm{M}_{1}(\mathrm{TOC})-\mathrm{M}_{0}$ (TOC) $=2987-3035=-48$ million RUB. Hence, the expected cost savings of the construction project is 48 million RUB. Change in variance $\Delta \sigma($ TOC $)=\sigma_{1}$ (TOC) $-\sigma_{0}$ (TOC) $=247-394=-147$ million RUB. The spread of possible values of the construction project cost is decreased by 147 million RUB, which indicates significant specification of the forecast.

Thus, the construction project management team can achieve the expected savings by spending additional transaction costs. It affords them to reduce significantly the spread of random cost values, which indicates reduction in the risk level of the construction project. The construction project cost distribution charts before and after the risk response activities that required additional transaction costs are shown in Fig. 4 and Fig. 5. The shape of the graph demonstrates that the expected value of construction project cost has shifted to the left, and the range of values has decreased.

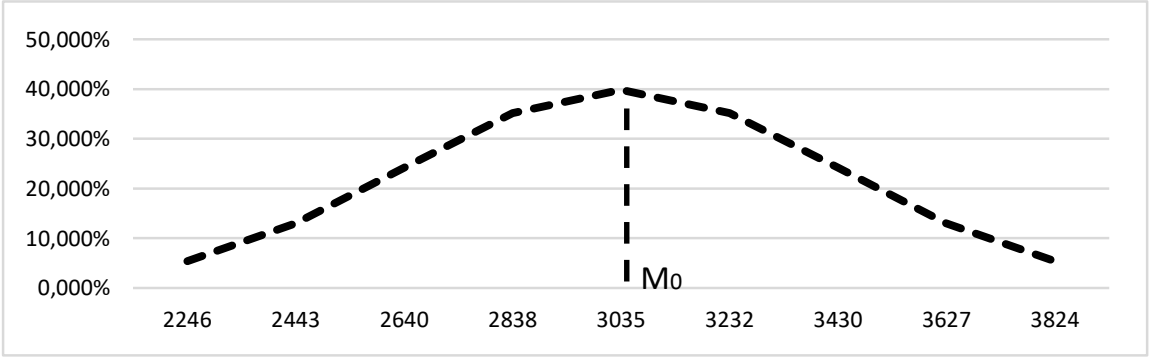

Fig. 1. The construction project cost distribution charts before the risk response. 


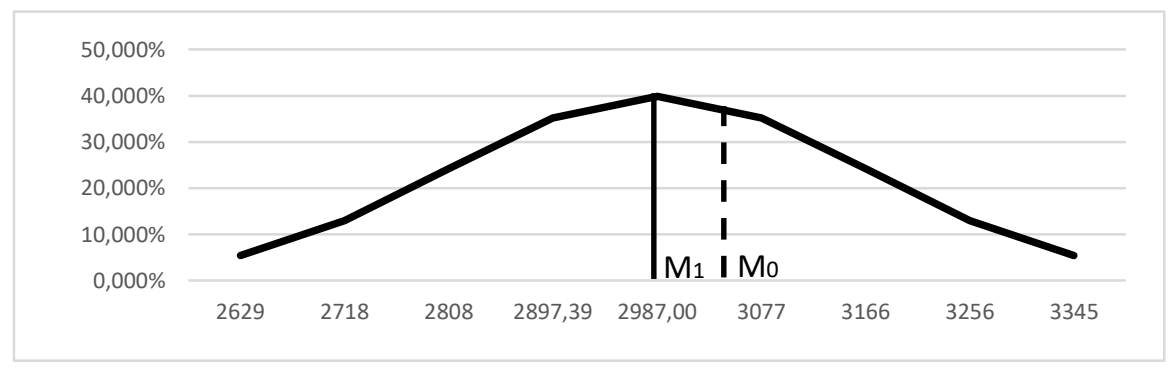

Fig. 2. The construction project cost distribution charts after the risk response.

Let us quantify these changes. We calculate the effectiveness of risk measures taken by considering formulas (11) and (12).

$$
\begin{gathered}
\mathrm{E}_{\mathrm{M}}=\frac{\mathrm{M}_{1}(\mathrm{TOC})-\mathrm{M}_{0}(\mathrm{TOC})}{\mathrm{TRC}_{1}-\mathrm{TRC}_{0}}=\frac{\Delta \mathrm{M}(\mathrm{TOC})}{\Delta \mathrm{TRC}}=\frac{-48 \text { million RUB }}{156 \text { million RUB }} \\
=-0,31 .
\end{gathered}
$$

The result reflects that for each additional ruble of transaction costs of the project it was possible to obtain the expected savings in total project costs of 0.31 rubles, i.e. $E_{M}<0$.

$$
\begin{gathered}
\mathrm{E}_{\sigma}=\frac{\sigma_{1}(\mathrm{TOC})-\sigma_{0}(\mathrm{TOC})}{\mathrm{TRC}_{1}-\mathrm{TRC}_{0}}=\frac{\Delta \sigma(\mathrm{TOC})}{\Delta \mathrm{TRC}}=\frac{-147,01 \text { million RUB. }}{156 \text { million RUB }} \\
=-0,94 .
\end{gathered}
$$

This result shows that for each additional ruble of transaction costs the project management team can reduce the spread of possible values by 0.94 rubles, i.e. $E_{\sigma}<0$. Thus, even in spite of the increase in the transaction costs associated with the response to risks, the expected value of construction project cost and the spread of its random values decrease. It proves that due to risk response activities construction project reduces the probability of its unsuccessful completion.

\section{Conclusions}

Construction project risk management model allows to establish a relationship between the risks in construction project and the level of transaction costs, which reflect the externalities of the negative impact on ecosystem. The proposed quantitative indicators can be used to assess the effectiveness of risk measures by tracking changes in the random parameters of the construction project when the value of transaction costs changes. The model and formulas can be applied in project management processes and data to identify the decrease in the variance of construction cost expected value and to assess the effectiveness of implementation risk response activities, including negative impacts on the ecosystem.

\section{References}

1. International Standard Organization, https://www.iso.org/obp/ui/\#iso:std:iso:14001:ed3:v1:en (2017)

2. Association for the Advancement of Cost Engineering (AACE) Total Cost Management Framework Second Edition 1996-2015, http://web.aacei.org/docs/defaultsource/toc/toc_TCM2.pdf (2017) 
3. International Standard Organization. ISO 21500:2012 Guidance on project management, https://www.iso.org/standard/50003.html (2017)

4. K.S. Corts, Journal of Law, Economics \& Organization 20(1), 230 - 260 (2004)

5. K.S. Corts, Journal of Law, Economics \& Organization 28(3), 550 - 568 (2012)

6. Project Management Institute. Project Management Body of Knowledge (PMBOK GUIDE) Fifth Edition, https://www.pmi.org/pmbok-guidestandards/foundational/pmbok (2017)

7. J.J. Wallis, D.C. North, Measuring the transaction sector in the American economy, 1870-1970 (University of Chicago Press, 1986)

8. A.N. Asaul, Snizheniye transaktsionnykh zatrat $v$ stroitel'stve za schot optimizatsii informatsionnogo prostranstva (St. Petersburg, 2008)

9. I.L. Vladimirova, P.I. Zemskov, Economics and management of managerial systems 3.2(21), 212-217 (2016)

10. I.L. Vladimirova, P.I. Zemskov, Innovations and investments scientific journal 2, 11-17 (2017)

11. P.I. Zemskov, Economics and entrepreneurship 3, 739 -744 (2017)

12. Yu.N. Cheremnykh, Microeconomics (Moscow, Advanced level, 2012)

13. I.L. Vladimirova, B.N. Porfiriev, Problems of theory and practice of management. International Journal 11, 8-19 (2015)

14. I.L. Vladimirova, A.N. Dmitriev, B.N. Porfiriev, A. Tsygankova, Standards and quality 10(940), 26-31 (2015)

15. I.L. Vladimirova, A.V. Sevostyanov, A.A. Tsygankova, Economics and management of managerial systems 4.2(14), 226-234 (2014)

16. A.V. Sevostyanov, A.A. Tsygankova, VI International Scientific and Practical Conference "Modern Problems of Project Management in the Investment and Construction Sphere and Nature Management, 128-134 (2016)

17. P.G. Grabovyi, S.N. Popelnyukhov, Real estate: economics, management 2, 78-81 (2013)

18. P.G. Grabovyi, A.V. Kapustkina, Real estate: economics, management 3, 17-22 (2015)

19. P.G. Grabovyi, N.I. Trukhina, E.Yu. Okolelova, Educational institutions. Technology of the textile industry 1(367), 52-56 (2017)

20. V.I. Resin, M.A. Motorina, E.Y. Pohily, I.L. Vladimirova, Real estate: Economics, Management 3, 23-29 (2015) 